\title{
PENGARUH MANIPULASI MEDIA TERHADAP KANDUNGAN ALKALOID VINKRISTINA KALUS DAUN Catharanthus roseus(L.) G.Don
}

\author{
Y. Sri Wulan Manuhara \\ Jurusan Biologi FMIPA \\ Universitas Airlangga \\ Surabaya 60115
}

\section{ABSTRACT}

The effect of the manipulation of the media on the vincristine alkaloid content in the callus of Catharanthus roseus (L.) G.Don were studied. This work was done as an effort for gaining the vincristine alkaloid through tissue culture which was expected to obtain a larger amount of the alkaloid.

Tissue culture of $C$. roseus was initiated from leaf explants on growth medium (MS supplemented with $1 \mathrm{mg} / \mathrm{l}$ 2,4-D and $1 \mathrm{mg} / \mathrm{l}$ BAP). After seven weeks incubation, with only once subculturing on the same medium, the proliferating calli were subcultured on a production medium (MS supplemented with $1 \mathrm{mg} / \mathrm{l} / \mathrm{AA}$ and $1 \mathrm{mg} / \mathrm{l} \mathrm{BAP}$ ) wich were containing different additional concentration of sucrose, BAP, tryptophan, and concentration of $50 \%$ basic medium of $M S$ from the standard. Eleven weeks-old calli were harvested from each treatment and dried for chemical analysed by thin layer chromatography on silica gel GF 254 using chloroform-acetontriethylamine as mobile phase. Rf value and uv spectra were used to identify vincristine, and concentration of vincristine alkaloid was determine by preparative thin layer chromatography with methanol solvent and measured by uv-vis spectrophotometer at 223 nom.

The maximum content of vincristine alkaloid was obtained from callus, wich was grown on the MS standard with an addition of $40 \mathrm{~g} / \mathrm{l}$ sucrose or $4 \mathrm{mg} / \mathrm{l} \mathrm{BAP}$ or and also $50 \%$ of the MS standard medium. Tryptophan addition as precursor could not induce the alkaloid vincristine forming.

Keyword : alkaloid -- vincristine -- Catharanthus roseus -- callus culture 